\title{
Korrespondensie
}

Kommentaar oor die artikel "Evaluasie van bestaande seleksiekriteria vir beeste in terme van totale kuddedoeltreffendheid" deur M.M. Scholtz en C.Z. Roux. SA Tydskrif vir Natulurwetenskap en Tegnologie, 1991, 10, 106-111.

Drr. Scholtz en Roux is bekend vir hulle vernuwende denke en kritiese beoordeling van gevestigde veeteeltpraktyke. 'n Bydrae soos dié, hierbo vermeld, word dus waardeer.

In hulle beoordeling van die vordering wat met die toepassing van die Nasionale Vleisbeesprestasietoetsskema oor 'n dekade gemaak is, het hulle egter twee aspekte uit die oog verloor wat genoem behoort te word.

1. Hulle het die vordering t.o.v. groeiprestasies op die plaas vanaf die sewentigerjare tot 1985 geëvalueer en tot die volgende slotsom gekom: "Daar was geen verbetering in groeiprestasie op die plaas nie (speen- en 18-maandemassa)." Dit is alombekend dat die sewentigerjare goeie reënjare in die beesweistreke was en dat ernstige droogtes baie beesboere gedurende die tagtigerjare geteister het. 'n Mens kan hulle bevindings dus grootliks daaraan toeskryf.

Die Bonsmarabeesras het weens sy getalle-oorwig ' $n$ baie groot invloed op die nasionale prestasietoetsresultate van stoetbeeste. Die groot toetrede van nuwe Bonsmaratelers met ongeselekteerde beeste tot die prestasietoetsskema gedurende die periode het 'n dempende invloed op die gemiddelde prestasievordering van die ras uitgeoefen, en dus ook in 'n mindere mate op die nasionale gemiddelde. Ek is daarvan oortuig dat met inagneming van die droogte die meer gevestigde telers wel goeie vordering gemaak het.

Dit is altyd gevaarlik om statistiese gegewens te aanvaar sonder om faktore wat dit kon beïnvloed het, ook in ag te neem.
2. Die outeurs verwys spesifiek na 'n verlenging van die interkalfperiode, tussen die eerste en tweede kalf, met $0,6 \%$ per jaar by die Bonsmara, m.a.w. 'n agteruitgang by 'n ras wat streng vir vrugbaarheid geselekteer word. Dit kan maklik verklaar word: die algemene gebruik is om vleisrasverse op 'n ouderdom van ongeveer twee jaar by die bul te bring om hulle eerste kalwers op drie jaar te hê. Met die vinniger groei wat deur seleksie teweeggebring is, kon baie Bonsmaraverse reeds op 'n ouderdom van ongeveer 20 maande gepaar word, wat meebring dat hulle op ' $n$ ouderdom van twee en 'n half jaar reeds 'n eerste kalf het (winterkalfseisoen).

Daarna word hulle in die meeste gevalle weer na 'n somerkalfseisoen oorgeskakel wat hulle'n tweede kalf op vier jaar besorg. Die stelsel verbeter vrugbaarheid en verseker dat byna elke koei 'n tweede kalf op vierjarige ouderdom het. Dit is egter die oorsaak van 'n verlengde interkalfperiode tussen die eerste en tweede kalf wat ook 'n koei se lewenslange gemiddelde interkalfperiode aansienlik verleng, selfs al het sy tien kalwers op twaalf jaar.

Interkalfperiode is 'n baie goeie maatstaf van vrugbaarheid by melkkoeie, maar by vleisraskoeie waar die boer die paarseisoene na willekeur beheer, het dit beperkte statistiese waarde.

$\mathrm{Na}$ my beskeie mening was die instelling van die Nasionale Vleisbeesprestasietoetsskema die grootste enkele bydrae wat vleisbeesboerdery in Suid-Afrika tot 'n baie hoër vlak as voorheen verhef het.

\section{J.F.W. GROSSKOPF}

President: Bonsmara Beestelersgenootskap van SA

\section{Toekomstige byeenkomste}

- Die internasionale simposium Africon '92 word van 22 24 September 1992 by die Royal Swazi Sun, Swaziland deur die Instituut vir Elektriese en Elektroniese Ingenieurs (Suid-Afrika) in samewerking met ' $n$ aantal ander organisasies aangebied. Die drie hooftemas van die simposium handel oor elektriese energiestelsels in Afrika, telekommunikasiestelsels in Afrika en tegnologiese opleiding in Afrika. Navrae: Sekretariaat Africon '92, FRD, Posbus 2600, Pretoria 0001. Telefoonnommer (012) 841-2422 (Rosemary Hewitt), faksnommer (012) 841-3791.

- 'n Nasionale konferensie, Katalise 92, word van 28 - 30 Oktober 1992 by die Berg-en-Dal-Konferensiesentrum,
Nasionale Krugerwildtuin deur die Katalisevereniging van Suid-Afrika aangebied. Navrae: Mev. Ute Duvenhage, Sekretariaat: Katalise 92, Posbus 14894, Verwoerdburg 0140. Telefoonnommer (012) 62-2466 (Dinsdag en Donderdag), (011) 716-2165 (Maandag, Woensdag en Vrydag), faksnommer (0148) 99-1666.

- 'n Internasionale simposium met die tema "Metal ions in solution" vind van 20 - 23 April 1993 by Malelane Lodge, Transvaal plaas. Navrae: N.V. Jarvis, AEK, Posbus 582, Pretoria 0001. Telefoonnommer (012) 316-5246, faksnommer (012) 316-5111. 


\section{Nuwe boeke}

Molluscan Neurobiology. 1991. Koninklijke Nederlandse Akademie van Wetenschappen Verhandelingen, Afd. Natuurkunde. 2de reeks, deel 88: p 1 - 360.

Die titel mag die indruk wek dat hierdie 'n handboek oor die neurobiologie van Mollusca is. In werklikheid bestaan die werk egter uit die bydraes wat in 1990 by die derde simposium oor die neurobiologie van Mollusca te Amsterdam gelewer is. Hoewel die boek in ses hoof afdelings verdeel is, staan elke bydrae onafhanklik van die ander in dieselfde afdeling. Soos in 'n geval soos hierdie verwag kan word, het 'n mens nie met 'n gestruktureerde werk te doen wat 'n basis lê en dan daarvandaan groei namate dit deurgelees word nie; die boek is dus nie bedoel as ' $n$ handleiding om ' $n$ basiese kennis oor die onderwerp op te doen nie. In werklikheid is 'n redelike goeie kennis van die morfologie, histologie en fiosiologie van die senuweesisteem nodig om alle dele van die boek ten volle te kan begryp. Opgeleide navorsers in bogenoemde en verwante dissiplines sou hierdie publikasie egter wel interessant en nuttig kon vind.

Soos in die voorwoord gemeld word, het die benadering by die betrokke simposium vanaf die klassieke neurofisiologie na die molekulêre aspekte verskuif. Daar word veral gebruik gemaak van die metodes wat deesdae in molekulêre genetika gebruik word. Daaruit het dan inligting voortgevloei wat die biochemiese en genetiese eienskappe van peptiedhormone en oordraers ophelder.

Die bydraes in die eerste van die ses afdelings maak onderskeidelik gebruik van mariene, varswater- en landslakke. Onder andere word die voedingsgedrag en kiefwerking by Aplysia ondersoek. Die sentra in die sentrale senuweesisteem wat hierdie funksies beheer, asook die betrokkenheid van neurosekresie word bespreek. Die gedrag van die varswaterslak Lymnaea stagnalis net voor en tydens eierlegging en die beheer wat die sentrale senuweesisteem daarop uitoefen, word toegelig. In nog 'n werk in hierdie afdeling word die morfologie van die dendriete van die reuse serebrale neurons van twee landslakke, nl. Rumina decollata en Achatina fulica bespreek. Die invloed van uithongering op die struktuur van hierdie dendriete word ook kortliks in oënskou geneem.

Die tweede afdeling het reseptore, ioonweë en intrasellulêre boodskappers as tema. Die bydraes is oorwegend deur navorsers aan mediese inrigtings en handel hoofsaaklik oor die stimulerende en vertragende uitwerking van neuroaktiewe peptiede op die neurons. Hulle invloed op asetielcholienreaksies word ook bespreek. Die rol van kalsium, natrium en kalium in die stimulering en vertraging van boodskapoordraging kom ook ter sprake.

Die derde afdeling bestaan uit sewe kort bydraes wat handel oor die groei, regenerasie en veroudering van senuweeelemente en die invloed van stowwe soos glutamaat op hierdie verskynsels. Die varswaterslak Lymnaea stagnalis is vir verouderingsverskynsels ondersoek en daar word tot die slotsom gekom dat veroudering teen verskillende tempo's by die onderskeie groepe neurons plaasvind. Nog 'n bydrae bespreek die invloed van veroudering op die funksionering van die pariëtale ganglion.
In die vierde afdeling wat gerig is op toegepaste mediese navorsing, asook in die sesde afdeling word aandag aan stowwe gewy wat uit parasiete soos bv. Schistosoma (wat o.a. bilharzia veroorsaak) onttrek kan word. Hierdie stowwe het 'n onderdrukkende invloed op die geslagsontwikkeling van die slaktussengashere. Die moontlikhede om sodanige stowwe aan te wend om die lewensiklus van die parasiet te breek, word genoem. Aandag word in verdere bydraes gegee aan die invloed van metaldehied en ander gifstowwe op die senuweesisteem. Een bydrae handel oor die invloed van epilepsie op die selle in die bukkale ganglion.

Die vyfde afdeling handel oor die sintese en opherging van neuropeptiede, asook oor die ontleding van neurohormone en hul invloed op die dier. Die sesde afdeling behandel o.a. aspekte van genekodering, asook die ontleding van die gif van die predatoriese slakgenus Conus en die invloed daarvan op die prooi.

Uit bostaande blyk dit dus duidelik dat hierdie publikasie eerder op die kundige navorser as op die voorgraadse student gerig is. Sodanige navorsers sou die werk dan ook moontlik bruikbaar vind vir vergelykende doeleindes en om wenke te kry vir eksperimente wat met ander diergroepe uitgevoer kan word.

\section{W.F. SIRGEI}

F.J. van der Merwe \& W.A. Smith. 1991. Dierevoeding. 2de hersiene uitgawe, Anim Sci (Edms.) Bpk., Meadway 16, Pinelands 7405 .

Hierdie hersiene uitgawe is 'n vernuwing van die reeds bekende boek, Dierevoeding, deur dr. (toe prof.) F.J. van der Merwe waarvan die eerste uitgawe reeds in 1970 verskyn het en in 1977 hersien is. Die inbring van ' $n$ jonger mede-outeur wat sy vinger gedurig op die pols van die voedingswetenskap kan hou, het nou die voortsetting van hierdie nuttige handboek verseker.

Die uitleg van die teks is 'n groot verbetering op dié van die vorige uitgawes. Die twee kolomme per bladsy en die duideliker opskrifte maak die teks makliker leesbaar en spesifieke onderwerpe makliker om te vind. Die tabelle is ook duideliker as in die vorige uitgawes.

Met die hersiening is die volgende onderwerpe bygevoeg of uitgebrei:

Voerontledingsmetodes - Kalorimetrie, kolorimetrie en aminosuurbepalings.

Verteerbaarheidstudies - Energie- en stikstofbalansstudies.

Voerprosessering - Maal, rol, stoomrol, verkorreling, ammonifisering.

Proteïendegradeerbaarheid in die herkouervoormae.

Droëmateriaalinname deur melkkoeie.

Hulpmiddels by melkbeesvoeding - BST, vette, niasien, buffers.

Voeding van koeie in die verskillende stadiums van laktasie.

Voerkraalafronding van beeste en skape - Ekonomiese oorwegings, groeistimulante. 
Varkvoeding - Rantsoene vir verskillende stadiums, doeltreffendheidstandaarde.

Perdevoeding - Oorwegings t.o.v. kondisie, omgewing, gedrag en werk.

Daarbenewens is die teks aangevul met 'n groot aantal tabelle oor bv. voersamestellings, aminosuurbehoeftes, proteiendegradeerbaarheid van'n verskeidenheid voersoorte, ruveselverteerbaarheid in melkkoeie, voedingsbehoeftes van melkkoeie en verse, waarde van verskillende voersoorte vir varke, en so meer.

Die groot hoeveelheid inligting wat in die tabelle opgeneem is, maak die boek, benewens sy waarde as handboek vir studente, ook 'n nuttige naslaanbron.

'n Onderwerp waaraan net geraak is maar wat meer aandag verdien, is die byvoeding van vleisbeeste en skape op natuurlike veld en aangeplante weidings. Dit lyk so asof die akademiese voedingkundiges dit probeer vermy en liewer aan hulle kollegas in die handel oorlaat om daaroor te adviseer.

Die inhoud van die boek is goed gebalanseerd vanuit ' $n$ student se oogpunt. Daar is geen deel wat oorbeklemtoon is nie. Na my beskeie mening is hierdie boek 'n ideale handboek vir studente in die veekunde en die veeartsenykunde en ' $n$ nuttige naslaanwerk vir boere wat met die voeding van diere te doen het.

\section{J.F.W. GROSSKOPF}

Kobus Maree. 1991. Word 'n wiskundewenner. J.L. van Schaik, 128 pp., prys R29,95.

Hierdie boek kan bydra om ouers en kinders se wiskundevrese die nek in te slaan. Dr. Maree slaag daarin om op 'n duidelike en eenvoudige wyse riglyne neer te lê waarvolgens ouers te werk kan gaan om hulle kinders aan te moedig en te lei om 'n sukses van wiskunde te maak.

Die boek spreek van die skrywer se kennis van die probleme waarmee leerlinge en hul ouers te doen kry tydens die daaglikse omgang met wiskunde.

Dr. Maree is duidelik 'n persoon wat ervaring het in die remediëring van leerlinge en ouers se sienswyse oor wiskunde. Sy benadering van die probleem is goed deurdink en behoort elke normale leerling te help om met harde werk en 'n positiewer aanslag sy wiskundepunt te verbeter.

\section{W.G. GREYBE}

D.J. Webb, P.D. Killworth, A.C. Coward \& S.R. Thompson. 1991. The FRAM Atlas of the Southern Ocean. National Environmental Research Council, 67 pp., prys $£ 100$.

Hierdie atlas is merkwaardig. In die eerste plek dek dit ' $n$ oseaangebied waaroor daar nog weinig bekend is - veel minder as oor die meeste ander oseane. In die tweede plek is dit nie ' $n$ atlas in die gewone sin van die woord, naamlik dat dit 'n versameling lesings of gegewens weergee nie, maar toon dit die resultate van 'n reuse rekenaarmodel.

FRAM staan naamlik vir die Fine Resolution Antarctic Model, 'n gemeenskapsnavorsingsprojek van die National Environmental Research Council in die Verenigde Koninkryk. Hierdie projek het die skep van 'n numeriese, driedimensionele rekenaarmodel vir die hele Suidelike Oseaan tot by $24^{\circ}$-suiderbreedte behels, maar met 'n ongekende oplosvermoë. Aangesien hidrodinamiese berekeninge oor die algemeen baie tydrowend op 'n rekenaar is, word die meeste oseaanmodelle beperk tot vier of vyf vlakke in die vertikale dimensie en tot 'n $100 \mathrm{~km}$-ruitenet of groter in die horisontale dimensie. Met so 'n beperkte keuse van oplosvermoë word die modellering van die belangrike bydrae tot die hidrodinamika deur mesoskaalturbulensie uitgeskakel. Sommige modelleerders bestudeer wel die mesoskaal, maar dan oor geografies baie klein oseaangebiede, om die benodigde rekenaartyd binne perke te hou.

Deur gebruik te maak van 'n Cray-superrekenaar kon die FRAM vir die eerste keer in die geskiedenis van die oseanologie hierdie twee gewenste aspekte kombineer, naamlik hoë geografiese oplosvermoë en 'n baie groot geografiese gebied. Vertikaal is tot 32 vlakke gebruik, terwyl die horisontale netwerk $1 / 2^{\circ}$ lengtegraad by $14^{\circ}$ breedtegraad was. Die gevolg is dat 5 miljoen netwerkpunte vir elke uur modeltyd bereken is.

Die atlas bevat die resultate van die model ná 6 jaar modeltyd, waartydens die bestaande hidrografiese data op 'n onkonvensionele wyse in die resultate geïnkorporeer en geïntegreer is. Die atlas bestaan uit twee hoofdele. Die eerste deel bevat kontoerkaarte van horisontale deursnitte waarop weergegee word: temperatuur, soutgehalte, druk sowel as die snelheidsveld. In die tweede deel word vertikale snitte vertoon, weer eens met die temperatuur, die soutgehalte en die snelhede van die beweging reghoekig op die snit self. Hierdie snitlyne volg dié wat beplan is vir die WOCE (World Ocean Circulation Experiment), 'n grootse, tien jaar lange, internasionale eksperiment en sal dus van groot hulp in die beplanning van daardie vaartlyne wees.

Die belangrikheid van hierdie kaarte en snitte is daarin geleë dat hulle 'n baie realistiese weergawe van die oseaan se geaardheid en beweging daarstel. Dit lyk dus of ons die fisika voldoende begryp om die oseaan korrek te modelleer. Sou 'n model van hierdie aard voortdurend gevoer kan word met intydse inligting van skepe op see, vrydrywende boeie met instrumentasie en met data vanaf satelliete, sou 'n mens die FRAM-weergawe in beginsel voortdurend kon aanpas om 'n realistiese, intydse beeld te gee van wat daar in die diepsee gebeur.

Die atlas is pragtig versorg en uitgegee. Dit is gedruk op hergebruikte, chloorvrye papier en het in ' $n$ internasionale kompetisie 'n goue toekenning gekry vir die kwaliteit van sy drukwerk. Dit is egter baie groot, wat die hantering en gebruik daarvan, na my mening, onnodig bemoeilik. Teen 'n spesiale aankoopprys van $£ 50$ vir studente en akademici, is dit beslis ' $n$ goeie en billike aanwins vir diegene wat in die vakgebied belangstel.

In hoe ' $n$ mate hierdie buitengewone atlas in die toekoms gebruik en benut gaan word, staan nog te besien. In die vakgebied oseanologie verteenwoordig dit egter alreeds ' $n$ besondere mylpaal. Dit is naamlik die langgekoesterde ideaal dat ons die oseaan se gedrag eendag sal kan voorspel op dieselfde wyse as tans dié van die atmosfeer. Hierdie ideaal lê nog in die verskiet, maar die publikasie van die FRAM-atlas is ' $n$ beduidende en stewige eerste tree in daardie rigting.

J.R.E. LUTJEHARMS 